Canadian University Music Review

Canadian University Music Review

Revue de musique des universités canadiennes

\title{
Feminist Theory and Music II: A Continuing Dialogue: Eastman School of Music, Rochester, New York, 17-20 June 1993
}

\section{Virginia Caputo et Roberta Lamb}

Numéro 14, 1994

URI : https://id.erudit.org/iderudit/1014317ar

DOI : https://doi.org/10.7202/1014317ar

Aller au sommaire du numéro

Éditeur(s)

Canadian University Music Society / Société de musique des universités

canadiennes

\section{ISSN}

0710-0353 (imprimé)

2291-2436 (numérique)

Découvrir la revue

Citer ce compte rendu

Caputo, V. \& Lamb, R. (1994). Compte rendu de [Feminist Theory and Music II: A Continuing Dialogue: Eastman School of Music, Rochester, New York, 17-20

June 1993]. Canadian University Music Review / Revue de musique des

universités canadiennes, (14), 182-187. https://doi.org/10.7202/1014317ar

All Rights Reserved (c Canadian University Music Society / Société de musique des universités canadiennes, 1994
Ce document est protégé par la loi sur le droit d'auteur. L'utilisation des services d'Érudit (y compris la reproduction) est assujettie à sa politique d'utilisation que vous pouvez consulter en ligne.

https://apropos.erudit.org/fr/usagers/politique-dutilisation/ 
ensuite à montrer qu'une autonomie du diachronique est également justifiée. C'est à partir du moment où on veut passer de la description immanente à l'explication historique et, de façon plus générale, poïétique, que la question de mise en rapport des deux types de discours se pose. On peut caractériser leur différence en opposant le « pigisme » du discours historique et le systématisme des approches immanentes. Enfin, on peut définir le point de contact possible entre musicologie historique et music theory comme la recherche de la pertinence poïétique paramètre par paramètre selon un aller-retour entre analyse immanente et poïétique.

\section{Feminist Theory and Music II: A Continuing Dialogue Eastman School of Music, Rochester, New York 17-20 June 1993}

\section{Virginia Caputo and Roberta Lamb}

Feminist Theory and Music II did advance the dialogues begun at the first such conference held two years ago, and, it seems, the dialogue will continue. Before we left Eastman, the University of California at Riverside was named as the location for the third (1995) conference. Feminist Theory II was much larger, of very high quality, no less provocative, and included more Canadians than the original conference. Five music education-related presentations - a majority within the conference - were Canadian, along with one theory paper and five musicology papers. In fact, so many Canadians registered for the conference that we spontaneously arranged a 'Canadian Caucus' dinner attended by about twenty!

The conference was organized around concurrent sessions scheduled over three days which presented the usual dilemma to those who did not want to miss anything. Lecture/recitals and 'composers on their works' were scheduled for late afternoons. Study sessions, as well as regular sessions, and concerts filled the evenings. Approaches and topics were varied, diverse, and controversial. Broader issues addressed included questions of theory, analysis, practice, patronage, theories of reception, 'voice,' the body, race, and sexualities. Musical examples ran the gamut from k.d. lang to Giovanni Sances, Billie Holiday to Claude Debussy, Clara Schumann to Libby Larsen, and Taarab to Prespa Albanians.

The conference plenary address, "Feminist Queries about Theory and Analysis," was an SMT reprise, updated and (according to the panel) presented to a much more receptive audience. Versions of most of these papers by Fred Maus, Marion Guck, Susan McClary, Marianne Kielian-Gilbert and Suzanne 
Cusick will be published in various music theory journals. Each presentation (too dense and thorough for this brief summary) discussed some aspect of what music theory is and how it is affected by feminist analysis, especially when one considers the theorist-as-listener, personal reflections and experience-oriented approaches. We highly recommend music scholars within all areas read these articles as they become available. There were another twenty-six fascinating sessions, so we find it impossible to review all our favourites within a short essay (nor can we speak to those presented simultaneously). We note the following presentations for their quality, tackling of a new or controversial topic, or particular contribution to feminist scholarship in music.

The concert music included historical and contemporary women composers of fine quality. In our opinion, one of the best concerts was performed by "ECCE!" ("Behold!," also Empire Chamber Concert Ensemble), an ensemble consisting of Eastman graduates and graduate students committed to a high standard of performance of contemporary music. Though primarily choral, "ECCE!" includes a woodwind quintet and piano. "ECCE!" performed choral music by American composers Williametta Spencer, Louise Talma, Ellen Taaffe Zwilich, Judith Lang Zaimont, Alice Parker, and Libby Larsen.

Some very interesting themes repeated and developed throughout the conference. Judith Butler's postmodern theories of gender as performance were borrowed and applied within all areas of musical scholarship represented. Due to the importance of performance in music, this extension of Butler's work seems most appropriate. One stunning example of Butler's theories concerning the performance and reception of gender and sexuality, wherein the gendered self is constituted through the performer, was Suzanne Cusick's paper, "Feminist/ Music Theory: A Question of Minds and Bodies?" Cusick focused on the presence of the body in music (a subject often denied by music theorists), articulating concepts of an embodied music theory. Cusick suggests that the analysis of musical texts as scripts for the performance of complex social relationships can be as fruitful as the analysis of the notes of the score. She noted the virtual elimination of questions about the body in mind-body relationship models, while on the other hand, this element is crucial to a feminist theory of music.

Similarly, Linda Dusman brought in Butler's theories about reception of gender and sexuality, as well as its performance, in her work on music reception. Dusman looks at the creation of an alternative paradigm for the reception of contemporary music, one that empowers a multiplicity of interpretations of these new works. Gender and reception theories were the focus of papers by Sanna Pederson and Randi Patterson as well. Beginning with a Harlequin romance, Harmonies, and a New York Times article on using sex to advertise classical music, Pederson examined "Absolute Music as Pure 
Pleasure" as a concept embodied in 19th-century German aesthetics. On the other hand, Patterson identified rhetorical appeal through a detached aesthetic or a sensual, musical language, both of which are hierarchic. Patterson illustrated écriture féminine as a means of moving out of these hierarchic patterns through an examination of Andrew Lloyd Webber's Phantom of the Opera.

Many more researchers examined the role of performance and the place of the body in music. Roseanne Kydd investigated epistemological processes in relation to performance and composition opportunities, specifically those of Fanny Mendelssohn Hensel. She concluded epistemological frameworks marginalized Hensel's position in music. Laura Caviani and Kari Veblen (through their interviews with Marian McPartland, Joan Wildman, and Eliane Elias) examined another aspect of performance: how musicians structure improvisation and the cultural context of teaching, learning, and creating/ performing jazz. They found that all three embrace collaboration in their work and are inspired by the arts, even though each woman approaches creativity quite differently. Jennifer Fisher explored the ways in which the ballet experiences of selected North American women affected their lives, reporting on ballet's emotional, physical and other effects. She dealt with the ballerina as both a regressive role model and a figure of strength for young girls, and concluded that the realm of ballet is not so straightforward as the stereotype, but a contradictory and contested terrain.

A second major theme worked with the images of violence in music, whether in country music, Prélude à l'apres-midi d'un faune, 'cock-rock,' Lulu, music video, seventeenth-century chaconne, or music education. Rape, wife abuse, and sexual harassment were some of the issues of violence discussed. The musical examples occurred narratively within the text or metaphorically through the music and were analysed in terms of eroticised violence, in addition to the sociological situating of musical experiences. For example, Charles Batson argued that Debussy retained the clarity of violent rape found in Mallarmé's text within the music and that the listener may, in some ways, be complicitous in the rape. In another paper, Lori Burns interwove a formal analysis of the music of the 1962 song "Johnny Get Angry" with k.d. lang's performance style as represented on lang's 1985 videotape of the song in concert. Burns asserted that lang constructs the female image as active agent rather than passive victim through her parody of male and female role stereotypes, even as the video performance portrays domestic violence. Lydia Hammessley's brilliant analysis of a Giovanni Sances cantata reveals the contradictory narratives of musical and verbal text. It becomes clear that the music masks the gravity of the woman's story in this cantata, wherein the 
narrative reads like a rape, but musically sounds like a flirtation. In other words, she said no but meant yes. Hammessley is a most careful scholar; her interpretation unfolds clearly in the musical score.

While the previous papers were explicit in addressing violence in music, Janika Vandervelde and John Welcke asked "How can we justify using 'cock'rock as topics for study in public school classrooms and institutions of higher learning?" Vandervelde and Welcke teach in an arts high school where the forms of music are clearly separated by sex: female music students are most likely to study classical and the male students rock. The student compositions presented at the conference were by male students only and were based on 'early ejaculation syndrome' and a 'seduction fantasy.' For some of us, this was a disturbing session in that the issue of violence represented within the music was not addressed, although it was very apparent.

Other education-related presentations included Roberta Lamb's "In the Midst of a Mentor Muddle," based on work-in-progress that explores women's experiences of the mentor/apprentice model of music education. The issues Lamb addresses are very delicate and sometimes reveal disturbing information about the experiences of women in music institutions, drawing important links between pedagogy, artistry and power. As a result of this work, Lamb hopes to uncover alternative, more egalitarian pedagogical models. In "Music for RedBlooded Men," Julia Koza analyzed choral methods texts published between 1982-92, finding they were little different from those published at the beginning of the century in their limitation of gender discussion to the absence of males in singing ensembles. She demonstrated, through numerous examples, that these texts are both misogynistic and homophobic, grounded in essentialist assumptions based on binary constructions. Of concern to Marcia Citron were issues related to teaching the canon of the university music history curriculum. She suggested one way to bring women into the canon is to consider women's work in relation to their own tradition and the musical mainstream, rather than in an either/or position. Citron explored the notion that the socio-historical setting of works refutes the transcendence of the cannon.

Virginia Caputo, Andra McCartney, Karen Pegley, and Austin Clarkson organized an excellent panel on music technology as gendered, "Gendered Images and Images of Gender in the Interactive Classroom." Caputo's presentation framed the questions and links with the others. She noted that technology is not neutral, that music educators are faced with addressing 'malestream' knowledge and confronting balances of power. McCartney interviewed five women electroacoustic composers regarding their education as composers, and found that all placed value on women role models and collaboration, attended to gender symbolism, and used a wide variety of 
compositional technology. Pegley's research found students differed by sex in use of music technology. She commented that the structure of this music technology program values self-direction but not cooperation. Pegley concludes non-sexist teaching is inadequate; we need to be anti-sexist. Clarkson focused on receptive listening in the middle school and gendered images in aesthetic experience (conscious and unconscious) through the paradigm of an interactive aesthetic environment. Clarkson postulates that the aesthetic experience is one of intersubjectivity and creativity.

While the three major themes of the conference-performance, violence and body - permeated Feminist Theory II, race/ethnicity and sexual orientation received specific attention also. Ellie Hisama and Susan Cook explored the lives and music of Joan Armatrading and Billie Holiday, respectively, to examine the ways their own identities, including race, gender and sexuality, were encoded in their music. Cook inquired into the ways Holiday's selfdefinition as "Lady Day" was a way of attaining legitimacy as a black woman/ performer both within the male-dominated world of jazz and within a larger racist society. Travis Jackson incorporated performance as ritual into his explication of African-American women in jazz, pointing out the complexity of the race-gender signifier in a music where women are identified as antithetical to the already marginalized music of jazz itself.

Another previously marginalized subject, lesbian and gay identities, was featured in several sessions and apparent in many papers. None, however, were as well-performed or received as Martha Mockus' "Lesbian Desire in the Music of Desert Hearts." Mockus examined the issues and politics of 'visibility' through an analysis of the Desert Hearts soundtrack, wherein she offered an alternative reading of this cultural text which claims to name and yet conceals lesbian existence. Through her 1950s-style performance and her cogent analysis, Mockus demonstrated that the assimilationist narrative of the film is sabotaged by the contradictory message of the film score through frequent use of the 'wrong' music and its butch-femme aesthetic. Questions of differences were featured by other presenters as well. For example, J. Michelle Edwards scanned a variety of sonic strategies women use to challenge the line between "sound" and "noise." With the music of Galas, Oliveros, and Byer, among several featured composers/performers, Edwards suggested their sonic strategies critique social configurations, pose new modes of interaction, and help to create alternative realities.

Different ways of thinking about traditional music theory were apparent in several papers. David L. Code addressed the gendered terms of music theory in "[Not equal]: Feminism, Tuning, and Theory Pedagogy." He analyzed tuning and temperament through feminist theory to demonstrate the exclusive 
ideologies involved in the (non)teaching of tuning in beginning theory. This sophisticated analysis questions why we organize music theory as we do. Code thought he might be a SNAT (sensitive new age theorist). Rebecca Green and Brian Hyer presented distinctive views on tonal relationships in eighteenthcentury music theory. Hyer focused on the ways figural language plays a key role in the rhetorical gendering of the tonic. He emphasized the narrative behaviour of listeners in the process of engendering music. Green explored the ways in which the triad is engendered in eighteenth-century treatises by Rameau, Rousseau and others. She demonstrated links between gender systems and reproduction metaphors in some mainstream treatises from this period. Green focused on Rameau's isolation of the triad as the basic music unit derived from nature in order to demonstrate the ways gendered discourse in music theory is used to support certain dichotomies.

One of the strengths of Feminist Theory and Music as an on-going conference is the inclusion of musicology, music theory, ethnomusicology, music education, and composition within one meeting, a challenge that creates space for an integrative approach to our disciplines. This second conference was much more inclusive than the first in that more people of colour participated and more music education sessions were scheduled. While sessions were well-attended, it appeared that musicologists and theorists were not as willing as ethnomusicologists and music educators to attend sessions in a sub-discipline other than their own. As Susan McClary indicated in "Paradigm Dissonances," interdisciplinarity is crucial to our understanding of music, not only as a formal structure, but also as a socio-cultural phenomenon that overlaps music theory, cultural studies and feminist criticism. We think the challenge of working together across our specialties within feminist music scholarship is well worth the continued effort, and encourage conference organizers to maintain and enhance the steps already taken in this direction.

Both of us presented research at Feminist Theory and Music I (Minneapolis, 1991), and, although we find that the enthusiasm of the initial conference can never be matched, Feminist Theory II had an assuredness not seen earlier. The confidence with which presenters spoke on particularly controversial issues, the ease in discussing topics previously marginalized, and the breadth of topics addressed, attest to the vitality of feminist scholarship in music. While many of us feel there is so much more feminist research to be undertaken in musicology, ethnomusicology, music theory, and music education, it is encouraging to see the Feminist Theory and Music conferences growing stronger as a means for feminist networks and dialogue in music scholarship. 